\title{
New French genome centre aims to prove that bigger really is better
}

Paris. Were it not for the big steel double helix outside, the world's largest gene-mapping laboratory might be mistaken for just another office building in one of the industrial parks that dot the countryside south of Paris. But the illusion is quickly dispelled. Above the ground floor, where technicians

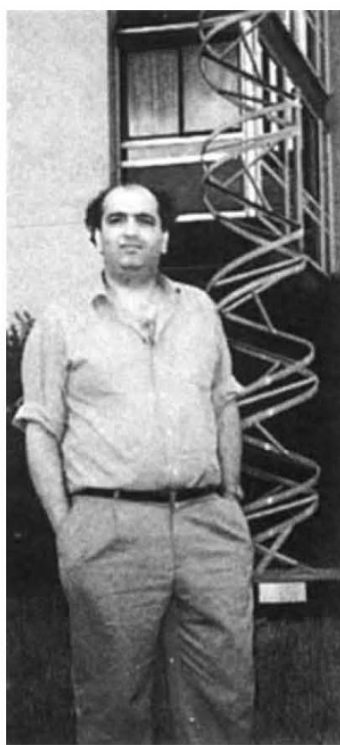

Daniel Cohen is winning converts to industrialscale gene mapping.

teach children with genetic diseases to use voice-operated computers, lie rooms of robots - the makings of an industrialsized 'experiment in scale' that may be the closest thing to big science that biology has ever seen. In full operation for only a few months, the Généthon, as it is known, has caused $\mathrm{g}$ e $\mathrm{n}$ o $\mathrm{m}$ e researchers around the world to re-

think their assumptions about the best way to complete the ambitious project to map and sequence the human DNA molecule.

Last month, Généthon researchers took the genome world by surprise when they revealed they had already finished a map covering some 28 per cent of the genome and almost the entire chromosome 21 . Daniel Cohen, director of the Paris-based Centre d'Etude du Polymorphisme Humain (CEPH) and the driving force behind the Généthon, told a meeting at Cold Spring Harbor Laboratory in New York state that he expects to be able to extend the map to cover 90 per cent of the genome by the end of the year.

But what really caused a stir was the way in which Cohen had collected the data: instead of using scientists, he had technicians running an array of automated gene machines that exist only as prototypes. The Généthon demonstrates an almost blue-collar approach to biology. More assembly line than ivory tower, the laboratory exists mostly to produce genetic information that other scientists will use.

The news that an industrial-scale gene mapping facility was not only up and running but also pumping out data faster than virtually any other group has caused US researchers to question their approach.

"It's impressive", says Mark Guyer, assistant director for program coordination at the National Center for Human Genome Research within the US National Institutes of Health (NIH). "It also confirms what we've been hearing from some of our own people about the advantages of scale. I'm not sure we can set up something that exactly duplicates their set-up, but in terms of learning the lesson of the industrial approach, we can definitely apply those sort of techniques to US operations."

Another convert is Eric Lander, a mathematician/geneticist and director of the genome centre at the Massachusetts Institute of Technology (MIT)'s Whitehead Institute. The Généthon "has demonstrated the tremendous advantages of scale", he says. Cohen has "done a lot to change people's perceptions. It's no longer unthinkable to take on whole genomic targets" rather than specific disease genes or chromosomes.

Lander, in fact, is more than an admirer; his laboratory has begun to collaborate with Cohen's group. And Cohen is expected to take a part-time position at MIT later this year as the first step in a major collaborative centre (see story below).

The Généthon itself is every bit as startling as its results. The $\$ 10$-million central facility is a large room, ringed with 20 robots, surrounding a central climate-controlled computer installation. The robots, which automate the DNA fingerprinting process, were developed by the French company Bertin as part of the European industrial collaboration Eureka Labimap 2000.

Each robot can perform Southern blots - a technique to distinguish DNA fragments by the characteristic bands they leave after gel electrophoresis - on 16 gels (with 20 lanes each) a day. Together, the machines have the potential to process more than 6,000 DNA samples a day. Yet the entire operation requires only five technicians.

Elsewhere in the laboratory, 12 automated sequencers from Applied Biosystems Inc. are producing some 500 cDNA

\section{Will MIT be home to next big centre?}

Washington. Riding on the success of the Genethon and its industrial approach to genome mapping, Daniel Cohen wants to set up a companion laboratory at the Massachusetts Institute of Technology (MIT). Although the size of the centre is unclear, negotiations are under way for Cohen to take a part-time appointment at MIT; he has already begun to collaborate with Eric Lander, a geneticist at MIT's Whitehead Institute.

Cohen, director of the Centre d'Etude du Polymorphisme Humain, believes that he and Lander, with $\$ 20$ million and 100 to 200 technicians and researchers, could create a US analogue to the Paris-based centre. "When you want to do really well, you get the right environment. The United States is the best for technology development", Cohen says. "We have done the most that is possible in France."

Lander is equally enthusiastic about the collaboration but more cautious about its scope. "I don't know where I'd put another 20 people, much less $200 "$, he says. He confirms that "we're considering a more extensive collaboration", but says that "we'll have a better idea of what we're doing in two months".

The two scientists have much in common. Lander is a mathematician-turned-geneticist; Cohen got his first degree as an engineer. Both researchers favour what they call a 'whole genome' approach to genetic mapping.

"Clearly chromosomes are important things, but mapping them per se requires chromosome-specific reagents, which have biases", Lander explains. "On a pure efficiency basis, whole genome approaches are the best - you can take whole DNA libraries. The reason [Cohen] and I get along so well is that we both agree that the whole-genome approach is the right way to go." He is also taken by the challenge of applying large-scale techniques to the world of small science.

Mark Guyer, assistant director for programme coordination at the US National Center for Human Genome Research, says that the US project has become "philosophically receptive" to several larger centres, such as the one Cohen and Lander have in mind. A year or two ago, such an idea would have outraged biologists concerned about an erosion of support for smaller laboratories. But Lander and Cohen have proved that production-scale approaches can be remarkably efficient, and it is hard to argue with success. 
sequences a week. A prototype 'spotting machine' (or, more formally, a multi-purpose clone-handling machine) can prepare 300,000 Yeast Artificial Chromosomes (YACs) in a day virtually on its own. And a prototype 'pooling machine' (known around the laboratory as Barbara) uses a special algorithm to combine automatically DNA samples from 12,288 wells into a much smaller number of pooled samples, which are then screened. This pooling process can reduce screening time by a factor of 10 .

Surrounded by such technology, Cohen is confident that he can handle the entire genome. He intends to clone random DNA fragments, each more than one million bases long, in the special 'megaYACs' that researchers at CEPH have developed. Combined, this library will cover 90 per cent of the genome.

Généthon cannot do everything - the genome project also requires researchers to fill in the gaps, order the sequences to form a usable map, find genes and their functions and actually read the sequences base by base. But Cohen's accomplishments are impressive, and the megaYACs and library he promises have won applause on both sides of the Atlantic.

Officials from several national programmes (including the United States) see the Généthon as a model for similar facilities in their own countries. The laboratory's industrial approach - a central hightechnology mapping resource that can be run by a network of researchers from smaller groups - appears to be a powerful idea. But Cohen warns that the factors that led to the creation of the Généthon may not be easy to reproduce.

Cohen says that the laboratory owes its existence to "four miracles". The first is CEPH, started in 1983 by immunologist and Nobel prizewinner Jean Dausset and Cohen, and its early embrace of industrial approaches. The second was Bertin's willingness to pay for the development costs of robots based on old technology - Southern blotting - rather than waiting for the technology to improve. As it turned out, older technologies, when automated and perfected, can often outperform newer methods.

Perhaps the most important miracle and the hardest to reproduce elsewhere was the support of the French muscular dystrophy charity, AFM. Headed by Bernard Barataud, a bearish former electrical engi-

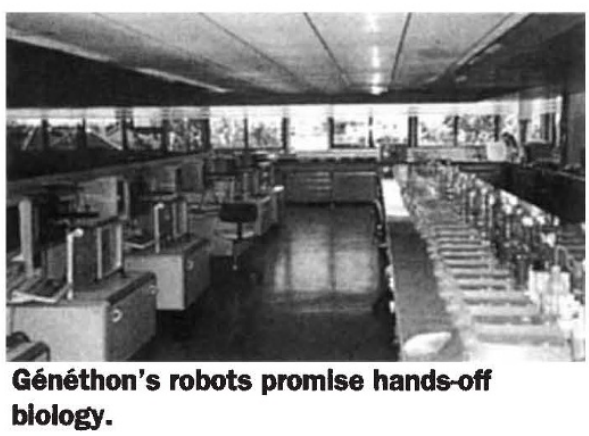

\section{Industrial in more than name}

Paris. The Généthon may soon have real industrial partners to go with its industrial approach to the genome project. Officials at the massive gene-mapping laboratory are planning to make it the core of an public-private consortium they call a Genepôle. Companies are being invited to set up complementary laboratories near the Généthon in Evry, south of Paris, where industrial researchers would work side by side with Généthon scientists to turn gene-mapping technology into products.

The first such collaboration is expected to be in software for sequence analysis; discussions are already under way with IBM. Another technology nearing commercialization is biological robotics, an area in which French industry has already shown an interest. Daniel Cohen, director of the Centre d'Etude du Polymorphisme Humain (CEPH), which runs the Généthon's mapping effort, says that he hopes to have companies on the site within a year or two. He says that the government would prefer that French companies are involved at the beginning, but so far there seems to be no serious opposition to participation by US companies as well. Most of the interest, in fact, has been from US companies and venture capitalists. Cohen expects that the nonprofit side of the collaboration - $\mathrm{CEPH}$, the French muscular dystrophy charity AFM and the government - would pay for the basic research, and that the companies would pay for the development of marketable technology.

C.A.

neer, AFM has been conducting telethons that typically raise more than $\$ 15$ million a year for genetics research, of which about $\$ 13$ million goes to the Généthon. The fourth miracle, Cohen says, is that the French genetics community did not try to stop him. His success, he believes, lies in avoiding the kind of politics that would probably sink such an audacious effort in the United States or Britain.

For those thinking of starting their own Généthon, Cohen warns that "finding one miracle is hard enough; another four miracles may be impossible." Nevertheless, the lessons from the project may have broad applications.

Piotr Slonimski, the new director of the French genome project (and one of the principal organizers of the 147-team effort that completed the sequence of the yeast genome last month [see Nature 357, 38; 1992]), compares the Généthon model to a mainframe computer with many users. In contrast, the yeast project more closely resembled a network of smaller computers linked together. The secret, he says, is applying the right model to the problem at hand. Although biological analysis is often best done by a network, Slonimski says, physical mapping is better accomplished at central facilities such as the Généthon.

Having proved its thesis that an industrial-scale approach can work in genetics, the Généthon is fast becoming a valuable international resource. Some 20 per cent of its effort is now spent on work for others. More than 50 outside laboratories, including about 20 in France, 30 in the rest of Europe and a few in the United States, now send their samples to the laboratory for analysis. Data sharing does not seem to be a problem; Cohen plans to make his megaYAC libraries available this summer, and he promises not to patent gene sequences in the absence of knowledge of their function.
Despite the acclaim, Cohen is not surprised by the project's success. "This is norisk research", he says. "This is easy. You put in one dollar and you get one thing; you put in two dollars, you get two things." $\mathrm{He}$ says he never doubted that it would work, nor that it could grow.

Although nearly everyone agrees that the laboratory has been an eye-opening achievement, they point out that much of the productivity is still only potential. Getting the long sequences is one thing, ordering them is quite another. "What they have is a plan to make a physical map, but it isn't there yet", says one US researcher.

Some other researchers are simply offended by the whole industrial approach, or, as Cohen puts it, the "changing scale of biology", a complaint he quickly dismisses. "They, too, will have to use robots [some day], and they just hate it", he says. "They will cry for five or ten years and then they will forget it."

Christopher Anderson

\section{Serbs oppose leader}

Munich. The Serbian Academy of Science and Arts has called for the resignation of the Serbian president, Slobodan Milosevic, who, they say, makes the plight of Serbia "even graver" in his attempts to put Serbia back on the political map. The appeal is signed by more than 800 scientists and 3,000 other citizens. Belgrade's Institute of Physics, one of the largest in Yugoslavia, has also appealed to the United Nations to ensure that dangerous chemical plants are kept out of range of artillery fire. Its immediate concern is the SODA SA plant in Tuzla, in northeast Bosnia, which stores a hundred times more chlorine than was held at the Union Carbide plant in India at the time of the Bhopal disaster.

Allson Abbott 